\title{
Panel Discussion: The Current State of Blended Learning
}

\author{
Alex Koohang, Terry Smith, \\ and Kevin Floyd \\ Macon State College, \\ Macon, GA, USA \\ alex.koohang@maconstate.edu; \\ terry.smith1@maconstate.edu; \\ kevin.floyd@maconstate.edu
}

\author{
Robert Skovira \& Fred Kohun \\ Robert Morris University, \\ Moon Township, PA, USA
}

skovira@rmu.edu;

kohun@rmu.edu

\section{Gary DeLorenzo \\ California University of Pennsylvania, California, PA, USA \\ delorenzo@cup.edu \\ Introduction}

Blended learning is defined as a mix of traditional face-to-face instruction and e-learning (Koohang, 2009). Elearnspace (2005, par. 3) states that "Blended learning takes the best of both worlds and creates an improved learning experience for the student." Advantages of blended learning has been documented in the literature as convenience, flexibility, improved learning, improved student interaction, increased retention, reduced costs, and reduced seat time (Young, 2002; Garnham \& Kaleta, 2002, Elearnspace, 2005). There are many approaches to blended learning.

Driscoll (2002) placed blended learning into four categories. They are:

1. "To combine or mix modes of web-based technology (e.g., live virtual classroom, self-paced instruction, collaborative learning, streaming video, audio, and text) to accomplish an educational goal.

2. To combine various pedagogical approaches (e.g., constructivism, behaviorism, cognitivism) to produce an optimal learning outcome with or without instructional technology.

3. To combine any form of instructional technology (e.g., videotape, CD-ROM, webbased training, film) with face-to-face instructor-led training.

Material published as part of this publication, either on-line or in print, is copyrighted by the Informing Science Institute. Permission to make digital or paper copy of part or all of these works for personal or classroom use is granted without fee provided that the copies are not made or distributed for profit or commercial advantage AND that copies 1) bear this notice in full and 2) give the full citation on the first page. It is permissible to abstract these works so long as credit is given. To copy in all other cases or to republish or to post on a server or to redistribute to lists requires specific permission and payment of a fee. Contact Publisher@InformingScience.org to request redistribution permission.
4. To mix or combine instructional technology with actual job tasks in order to create a harmonious effect of learning and working." (Driscoll, 2002, par. 2)

Oliver \& Trigwell (2005) placed the definitions of blended learning cited in the literature into seven categories: 1) Mixing E-learning with Traditional 
Learning; 2) Mixing Online Learning with Face-to-Face; 3) Mixing Media; 4) Mixed Contexts; 5) Mixing Theories of Learning; 6) Mixed Learning Objectives; and 7) Mixed Pedagogies.

\section{Purpose}

The purpose of this panel is to create a forum for discussing three important and ongoing themes related to blended learning. The themes are 1) blended learning - an overview of empirical research; 2) blending the right stuff - creating the balance; and 3) designing the blend.

\section{Themes}

\section{Blended Learning - An Overview of Empirical Research}

Does blended learning contribute to improved learning? Does blended learning contribute to improved student interaction? Does blended learning contribute to increased student retention? Does blended learning reduce costs? Is blended learning flexible \& convenient for students?

The panel will discuss the recent empirical research related to the above questions.

\section{Blending the Right Stuff - Creating the Balance}

Osguthrope \& Graham (2003) asserted that blended learning must have an appropriate balance between face-to-face and online activities. The authors believe that "The balance for online and face-to-face components will vary for every course. Some blended courses, because of the nature of the instructional goals, student characteristics, instructor background, and online resources, will include more face-to-face than online strategies. Other courses will tip the balance in favor of online strategies, using face-to-face infrequently. Still others will mix the two forms of instruction somewhat equally." (Osguthorpe \& Graham, 2003, p. 228)

The panel will discuss what may be the suitable balance of activities in various blended learning settings.

\section{Designing the Blend}

Koohang (2009) asserted that once the balance of activities is in place for blended learning, attention must be given to the instructional strategies. The author further states that design of the blended learning must focus on student learning. Appropriate instructional design for both modes of instruction delivery includes sound pedagogical strategies and practices.

The panel will discuss various models of blended learning including the models that are empirically examined.

\section{The Structure of the Panel}

The panel will consist of three themes. They are: blended learning - an overview of empirical research; blending the right stuff - creating the balance; and designing the blend. Panelists will present one theme at a time. Audience will be invited to contribute to the discussion.

\section{References}

Driscoll, M. (2002). Blended learning: Let's get beyond the hype. LTI Newsline: Learning \& Training Innovation. Retrieved December 6, 2009 from http://elearningmag.com/ltimagazine/article/articleDetail.jsp?id=11755

Elearnspace. (2005). Blended. Retrieved December 6, 2009 from http://www.elearnspace.org/doing/blended.htm 
Garnham, C. \& Kaleta, R (2002). Introduction to hybrid courses. Teaching with Technology Today, 8(6). Retrieved December 6, 2009from http://www.uwsa.edu/ttt/articles/garnham.htm

Koohang, A. (2009). A learner-centered model for blended learning design. International Journal of Innovation and Learning, 6(1), 76-91.

Oliver, M. \& Trigwell, K. (2005). Can blended learning be redeemed? E-Learning, 2(1), 17-26.

Osguthorpe, R. \& Graham, C. (2003. Blended learning environments: Definitions and directions. The quarterly Review of Distance Education, 4(3), 277-233.

Young, G. (2002, March 22). Hybrid teaching seeks to end the divide between traditional and online instruction. Chronicle of Higher Education, A33-A34

\section{Biographies}

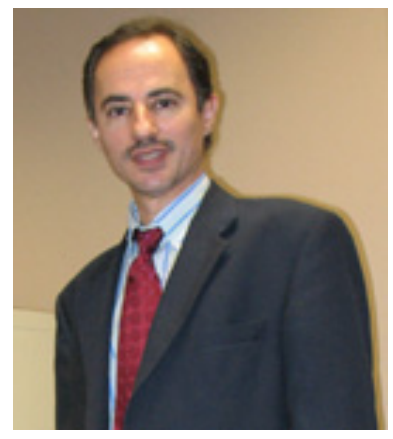

Alex Koohang is Peyton Anderson Eminent Scholar and Professor of Information Technology at Macon State College. He also serves as the Dean of the School of Information Technology at Macon State College. Dr. Koohang has been involved in the development of online education, having initiated and administered some of the earliest asynchronous learning networks. His current research interests are in the areas of e-learning, learning objects and open education.

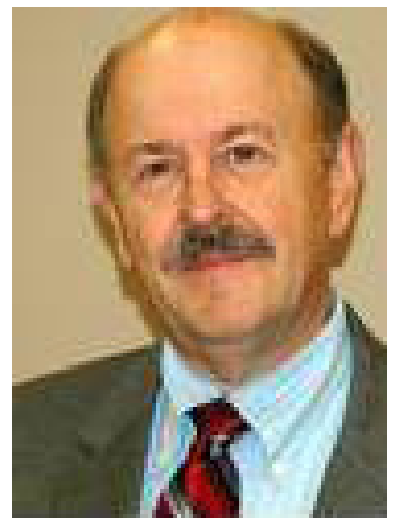

Terry Smith is an assistant professor in the School of Information Technology at Macon State College in Macon, Georgia. He holds a Ph.D. in Information Systems from Nova Southeastern University in Ft. Lauderdale, Florida and a M.B.A. from the University of South Florida in Tampa, Florida. His research interests include human computer interaction, Web and Internet technologies, E-business, Ecommerce, E-government, and E-Learning.

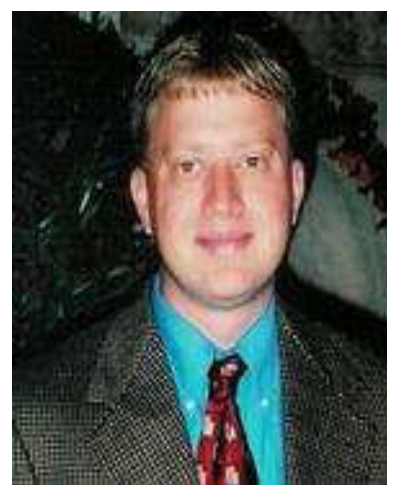

Kevin Floyd is an assistant professor of Information Technology in the School of Information Technology at Macon State College. He teaches in the areas of web development, web programming, and application development. His current research interests are in the areas of open source technologies, web accessibility, and student learning and engagement strategies. 


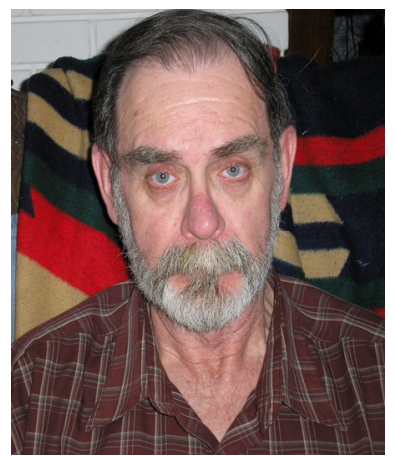

Robert Joseph Skovira is a University Professor of Computer Information Systems in the Department of Computer and Information Systems, School of Communications and Information Systems, at Robert Morris University, Pittsburgh PA USA. He teaches undergraduate and graduate (MS) courses including Java Programming, Secure Programming, Knowledge Management, Global, Economic, Social, and Ethical Issues of Computing, Decision Support Systems, Information Design, and Ethical and Legal Issues of Technology. In the Doctor of Science program he teaches Ethnography of Information Systems. He was a visiting professor at Comenius University, Bratislava, Slovakia, in 1997 and 2006. Dr. Skovira's research interests include information and information system use within organizations (politics of information, information system bias, secure programming), cultural and moral frameworks, decision making and knowledge mapping, and information design and thinking visually.

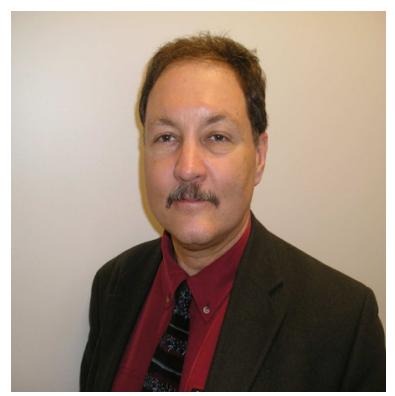

Frederick G. Kohun, Ph.D., Associate Provost and University Professor at Robert Morris University in Pittsburgh, Pennsylvania has more than 33 years experience as a professor, department head, and academic administrator in the information systems field. He holds a bachelor degree in economics from Georgetown University, graduate degrees in economics and information science, from the University of Pittsburgh, and a Ph.D. in applied history in technology from Carnegie Mellon University. At Robert Morris University he led the design and implementation of eight technology based academic programs at the undergraduate and graduate level (including a doctoral program) as well as the attainment of ABET-CAC accreditation. He is known both nationally and internationally from his numerous publications and presentations in health informatics, decision support, technological impact, and culture as well as his active involvement as an accreditation evaluator and team leader.

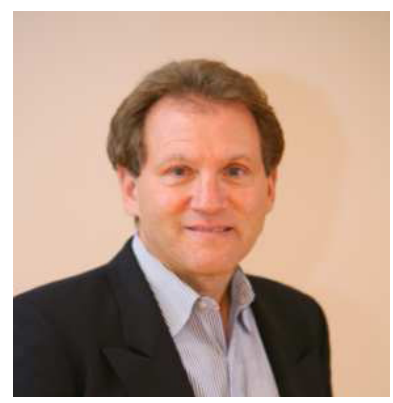

Gary J. DeLorenzo, D.Sc., Assistant Professor of Mathematics and Computer Science at California University of Pennsylvania in California, Pennsylvania, has spent more than 30 years in industry as programmer, analyst, consultant and manager before entering academia. In his academic career, he has gained a reputation as someone who brings people together, shares his industrial experience with students, and brings his energy and knowledge for collaborative efforts. He has led initiatives at the university in areas such as marketing and recruitment to increase student enrollment, service learning projects for information system majors, and startup business incubation projects. He and his students provide ongoing data base consulting and application support services for the John Heinz History Museum, Pittsburgh, PA, the largest history museum in Pennsylvania. He was a visiting professor at Robert Morris University in 2004 and 2008, and has presented and published his research both nationally and internationally. 